$\begin{array}{r}\text { ANGIES } \\ \text { NEW PERSPECTUE5 } \\ \hline\end{array}$ ANELOPHONE WORLD

\section{Angles}

New Perspectives on the Anglophone World

$11 \mid 2020$

Are You Game?

\title{
Video Introduction to Issue 11
}

Are You Game?

\section{Gilles Bertheau}

\section{(2) OpenEdition}

Journals

Electronic version

URL: https://journals.openedition.org/angles/3298

DOI: $10.4000 /$ angles.3298

ISSN: 2274-2042

\section{Publisher}

Société des Anglicistes de l'Enseignement Supérieur

\section{Electronic reference}

Gilles Bertheau, "Video Introduction to Issue 11", Angles [Online], 11 | 2020, Online since 01 November 2020, connection on 06 June 2022. URL: http://journals.openedition.org/angles/3298 ; DOI: https:// doi.org/10.4000/angles.3298

This text was automatically generated on 6 June 2022 .

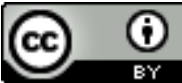

Angles est mise à disposition selon les termes de la Licence Creative Commons Attribution 4.0 International. 


\title{
Video Introduction to Issue 11
}

\author{
Are You Game? \\ Gilles Bertheau
}

This media file cannot be displayed. Please refer to the online document http:// journals.openedition.org/angles/3298

\section{Transcript:}

1 Hello! Welcome to the introduction of issue number 11 of Angles: New Perspectives on the Anglophone World, entitled "Are You Game?"

2 In this world where many adults and children share, even to the point of competition, the same passion for video games ("ludi" in Latin, "jeux" in French), the question of game / gaming / playing and its extensions assumes great topicality in terms of technique, æsthetic and - more negatively - medicine (with the phenomenon of addiction).

3 It also concerns philosophy and the opposition between real life and life by proxy, where "ludere" verges on "illudere, or even plunges one into the fiction of "mimesis", as in the theatre and the genre of the interlude.

4 This is why the subject of this issue was chosen, with a title - "Are You Game?" - that purposes to challenge the readers.

5 Games already existed in Antiquity, as the Egyptian dice from the British Museum show. Chess - the philosophers' game - is also a very old human invention, taking its origin somewhere in the East, perhaps in India.

6 For centuries the notion of game has raised questions and the serious aspect of this phenomenon appeared in the $17^{\text {th }}$ and $18^{\text {th }}$ centuries, related to the question of probabilities, the most famous image of which is Blaise Pascal's wager. In early modern Europe, and in England, the question of games, and especially games of chance, led to very animated and deep controversies among scholars and theologians. Dice in particular came under heavy attack from most Anglican ministers, as it depended solely on chance. Mainly considered a form of amusement, antique game already contained a lot of serious possibilities, through the metaphor of life balanced between 
chance and fate, famously illustrated by the "Alea jacta est" ("the die has been cast") allegedly uttered by Julius Cæsar crossing the Rubicon (according to Suetonius). It has now become a popular phrase in everyday life.

What do we mean when we speak of "game" and "play"? The Oxford English Dictionary provides a threefold answer: first amusement, fun, pleasure, then "an activity played for entertainment, according to rules" and finally all the senses related to hunting, in particular the animals that "are or have been the quarry of hunters".

8 You'll see in the Interlude an interesting instance where these different acceptations come into play.

9 As a matter of fact, when the sense of game is drawn towards hunting activities, it can provide another metaphor, that of the Passion of Christ (venatio Christi), compared to the stag chased and killed by the hunters.

10 The topic of game necessarily entails that of play, in the sense of entertainment, and with it the theatrical meaning of the word, already present in the Latin ludus, especially in the phrase ludus sccenicus, where playing a part is translated by the verb illudere. The Latin ludus and ludere are two words that produced a long list of derivatives in English like "ludic", "ludicrous", "ludology", "illude", "illusion" etc.; they also refer to leisure, free time (in Greek scholè) devoted to learning. Ludus also designates a school in Latin. So we shall see that game is not simply a futile activity and can conduce to education.

11 This issue does not mean to cover all the categories of game as defined by Roger Caillois in Les Jeux et les hommes: le masque et le vertige published in 1958, which was translated into English in 1961 as Man, Play and Games. It was written against the theories of Johan Huizinga's Homo ludens, written in 1938.

12 Caillois' categories are: games of chance (alea), games of competition (agôn), games of imitation (mimicry) and games of vertigo (illinx). The articles in this issue deal mainly with alea, even if video games imply competition.

13 The first three articles in this issue address the topic from a theoretical point of view and show the tight connection between game, reading and fiction. In her article "Play and Games in Fiction and Theory", Joyce Goggin inscribes her reflexion on reading fiction as a game into a wider consideration on what is called the "gamification" of today's world.

14 The complex meanders of reading as a game is also what Olivier Hercend invites us to think about through the notion of literature as "agôn".

15 Now if reading is a form of play, then Jean-Jacques Lecercle provides a good illustration thereof, as he takes pleasure in interpreting Jane Austen's Pride and Prejudice by analysing its recurrent play on the words "consequence" and "consequences".

16 The next two articles focus on gambling in the American context, with Bastien Meresse showing how, in Thomas Pynchon's novels, this capitalistic activity becomes a paradoxical way of resisting the rational rules of the world.

17 On her part, Julie Assouly studies American cinema and explains how the presence of women in this rather masculine environment allows for a reassessment of the myth of the American Dream.

18 The political implications of games are at the centre of Louise Fang's article on King John by Shakespeare where the ludic metaphors used by Shakespeare's characters reveal the tension between the roles of chance, providence and human agency in 
history. This is particularly true of the bowling game, as is confirmed by this engraving entitled The Catholick Gamesters, published during the Exclusion Crisis, in 1680.

19 A few decades after King John, George Wither's Collection of Emblemes is not simply one addition to the already long list of emblem books, since it includes a lottery game at the end. Although George Wither downplays the seriousness of what he called a "Recreation", Pierre Le Duff shows that there is much more to it than the mere incidental nature of lottery.

20 Lottery games are old and have offered cartoonists splendid occasions for mocking their contemporaries' morals, as in this pair of drawings, published in London at the end of the $18^{\text {th }}$ century, commenting on the shares of hopes and the disappointments brought by lotteries in British families.

21 Whereas pure chance governs lottery games, video game players must develop specific skills if they want to progress from one level to another and eventually to win what often turns out to be a harsh competition.

22 Game developers have gone a long way from the first Atari console marketed in the 1970s to the latest hyperrealist productions, such as Assassin's Creed and The Order 1886, both set in a graphic recreation of Victorian London which Nicolas Sigoillot analyses and assesses in his article. He explains how, beyond sheer entertainment of becoming a fictional character, these games are so designed as to enable the players to educate themselves by appropriating history.

Education is the endnote of this issue, with Jeni Peake and Alexandra Reynolds' article on the linguistic benefits of video games for speakers of English as a Second Language. Immersed in this gaming environment with their peers, French youths find it easy to learn new words and turns of phrases.

\section{ABSTRACTS}

This issue of Angles investigates the diverse aspects of the notion of game, gaming, gambling in the Anglophone world, today and in the past. The perspectives range from theoretical writing, literature, cinema, civilization, pedagogy to video games, in England and the United States.

Ce numéro de Angles s'intéresse à la notion de jeu dans le monde anglophone d'aujourd'hui et d'hier. La question est abordée des points de vue théorique, littéraire, cinématographique, civilisationnel, pédagogique et des jeux vidéo, en Angleterre et aux Etats-Unis. 


\section{INDEX}

Mots-clés: recherche, jeux, jeux vidéo, jeux d'argent, loterie, éducation, hasard, providence,

plaisir

Keywords: research, games, video games, gambling, play, lottery, education, chance, providence, pleasure

\section{AUTHOR}

\section{GILLES BERTHEAU}

A Senior Lecturer at the University François Rabelais of Tours and a member of the Centre d'Études Supérieures de la Renaissance (CESR, UMR 7323) since 2003, Gilles Bertheau is a specialist of English historical drama, more especially Jacobean drama. He has published an edition/translation of The Tragedy of Chabot/La Tragédie de Chabot by George Chapman and James Shirley (Paris, Classiques Garnier, 2016). He is also interested in King James I's political writings and the relations between authority and authorship in early seventeenth-century England.

Contact: gilles.bertheau [at] univ-tours.fr 